\title{
A STUDY OF WORKLOAD BEFORE AND AFTER RETIREMENT AT THE AGE OF 65 YEARS
}

\author{
BY \\ J. E. LUNN, M.D., PH.D. \\ Department of Preventive Medicine and Public Health, University of Sheffield \\ AND \\ W. H. R. WATERS, M.B., Ch.B. \\ General Practitioner, Hatfield and Dunscroft
}

The consultation rate in general practice is closely related to age. Lees and Cooper (1963), taking stock of 37 studies of general practices, commented that overall the patterns for consultation rates took the form of a step ladder for females, and a step ladder, broken by a dip in the 15-45 years age group, for males. Both distributions reached a maximum in the 65 plus group. The Research Committee of the Council of the College of General Practitioners (1962) showed a $50 \%$ increase in the rate of consultation for those persons aged 65 years and over compared with those aged 45-64 years.

A recent study of consultation rates in a mining area general practice (Rider, Waters, Charnock, and Lunn, 1969) has shown a more complicated pattern. Whereas the consultation rates for women followed the conventional pattern of increasing with age, the rates for men showed a large increase in the 45-64 years age group and a drop in the 65 plus group. It was thought that the need to certify unfitness for work was largely responsible for this pattern, and that the need probably had two components: (1) a higher morbidity rate among miners; and (2) the nature of mining work; an illness or injury which prevented a miner from working would not incapacitate him in many other occupations.

Clearly the consultation pattern in this practice merited further study to determine the effect of men's work on the demand for general practitioner services. This paper examines the consultation patterns of men who retired normally at the age of 65 years for the one-year period immediately preceding retirement and the one year immediately following retirement. The consultation patterns of their wives over the same two years are also examined.

\section{METHOD}

The records of all men born in 1900, 1901, and 1902 were extracted from the practice files. The records of men working past the age of 65 and of men retiring early were put aside. The remainder, retiring at 65 years in 1965, 1966, and 1967 respectively, were examined and data were collected of all surgery consultations for one year before retirement and one year after retirement. The records of the wives of these men were also extracted and similar data were recorded for one year before and one year after the husbands' retirement.

THE MeN

\section{FindinGS}

The sample contained 134 men, 79 miners and 55 non-miners. The occupations of the non-miners are shown in Table I.

Table II shows the surgery workload produced by these men for the year immediately preceding and the year immediately following their retirement. More of the miners consulted at the surgery in the year before retirement than the year after. Those who did consult the doctor did so for more episodes of illness, and for each episode of illness they consulted more often. These differences between

TABLE I

OCCUPATIONS OF THE 55 NON-MINERS

\begin{tabular}{|c|c|}
\hline Occupation & No. \\
\hline $\begin{array}{l}\text { Factory worker (various) } \\
\text { Transport worker } \\
\text { Farmer or farm worker } \\
\text { Labourer } \\
\text { Clerk } \\
\text { Various (e.g., caretaker, gardener, headteacher, batman, } \\
\text { rent collector, etc.) }\end{array}$ & $\begin{array}{r}15 \\
10 \\
8 \\
5 \\
3 \\
14\end{array}$ \\
\hline Total & 55 \\
\hline
\end{tabular}


TABLE II

SURGERY CONSULTATIONS FOR ALL ILLNESSES OVER A PERIOD OF ONE YEAR BEFORE AND ONE YEARI AFTER RETIREMENT AT AGE 65 YEARS

\begin{tabular}{|c|c|c|c|c|c|c|}
\hline & \multicolumn{3}{|c|}{ Number of } & \multicolumn{3}{|c|}{ Rates } \\
\hline & $\begin{array}{c}\text { Persons } \\
\text { Consulting }\end{array}$ & $\begin{array}{l}\text { Episodes of } \\
\text { Illness }\end{array}$ & Consultations & $\begin{array}{c}\text { Persons } \\
\text { Consulting \% }\end{array}$ & $\begin{array}{l}\text { Episodes per } \\
\text { person }\end{array}$ & $\begin{array}{c}\text { Consultations } \\
\text { per Episode }\end{array}$ \\
\hline $\begin{array}{l}79 \text { Miners } \\
\text { Before retirement } \\
\text { After retirement }\end{array}$ & $\begin{array}{l}75 \\
48\end{array}$ & $\begin{array}{r}222 \\
98\end{array}$ & $\begin{array}{l}836 \\
206\end{array}$ & $\begin{array}{l}95 * * * \\
61\end{array}$ & $\begin{array}{l}3.0 * * * \\
2 \cdot 0\end{array}$ & $\begin{array}{l}3 \cdot 8 * * * \\
2 \cdot 1\end{array}$ \\
\hline $\begin{array}{l}55 \text { Non-miners } \\
\text { Before retirement } \\
\text { After retirement }\end{array}$ & $\begin{array}{l}38 \\
37\end{array}$ & $\begin{array}{l}86 \\
66\end{array}$ & $\begin{array}{l}279 \\
161\end{array}$ & $\begin{array}{l}69 \\
67\end{array}$ & $\begin{array}{l}2 \cdot 3 \\
1 \cdot 8\end{array}$ & $\begin{array}{l}3.2 \% \\
2.4\end{array}$ \\
\hline
\end{tabular}

$* P<0.001 ; * P<0.01 ; * P<0.05$

the pre-retirement and post-retirement years are highly significant for persons consulting, for episodes per person, and for consultations per episode.

The non-miners show a different picture. The numbers consulting pre- and post-retirement were virtually the same. The numbers of episodes per person and consultations per episode were higher before retirement than after, but to a much lesser degree than in the case of the miners.

The surgery workload produced by the miners and the non-miners is remarkably similar during the year after retirement.

Certificates of incapacity for work were given to miners and non-miners at $83 \%$ and $75 \%$ respectively of the consultations during the year before retirement.

\section{THe WIVES}

The records of 103 wives were found. This number does not differ significantly from an expected number of 108 wives for 134 men in this age group, calculated from the 1961 Census figures for Thorne Rural District in which the practice is situated.

Records of 54 miners' wives were found, a further $22(28 \%)$ were dead, and three of the miners were unmarried. Records of 49 non-miners' wives were found, a further five $(9 \%)$ were dead, and one nonminer was unmarried. The excess of deaths among the miners' wives is in line with the RegistrarGeneral's 1957 figures which show an excess of deaths in this group.

Table III shows the surgery workload of the wives for the year immediately preceding and the year immediately following their husbands' retirement. Neither the miners' wives nor the nonminers' wives show any significant differences between the pre-retirement and post-retirement years for any of the rates measured.

The possibility exists that the drop in surgery workload after retirement could be accounted for by a rise in home visits. Unfortunately, the home visits could not be studied directly since no regular account of these visits is transferred to record cards, and the visiting books carry insufficient information to permit analysis. It was possible, however, to look at 7,945 consultations in the practice occurring over seven one-week periods. These showed that men aged 64 years sought 64 consultations (38 at the surgery, 26 in the home), and men aged 65 years sought 33 consultations ( 23 at the surgery, 10 in the home). It appears likely, therefore, that the workload drop on retirement affects both surgery consultations and home visits and is not simply a transfer of workload from the surgery to the home.

TABLE III

WIVES: SURGERY CONSULTATIONS FOR ALL ILLNESSES OVER A PERIOD OF ONE YEAR BEFORE AND ONE YEAR AFTER HUSBAND'S RETIREMENT AT AGE 65 YEARS

\begin{tabular}{|c|c|c|c|c|c|c|}
\hline & \multicolumn{3}{|c|}{ Number of } & \multicolumn{3}{|c|}{ Rates } \\
\hline & $\begin{array}{c}\text { Persons } \\
\text { Consulting }\end{array}$ & $\begin{array}{l}\text { Episodes of } \\
\text { Illness }\end{array}$ & Consultations & $\begin{array}{c}\text { Persons } \\
\text { Consulting \% }\end{array}$ & $\begin{array}{l}\text { Episodes per } \\
\text { Person }\end{array}$ & $\begin{array}{l}\text { Consultations } \\
\text { per Episode }\end{array}$ \\
\hline $\begin{array}{l}54 \text { Miners' wives } \\
\text { Before husbands' retirement } \\
\text { After husbands' retirement }\end{array}$ & $\begin{array}{l}37 \\
37\end{array}$ & $\begin{array}{l}78 \\
78\end{array}$ & $\begin{array}{l}178 \\
185\end{array}$ & $\begin{array}{l}69 \\
69\end{array}$ & $\begin{array}{l}2 \cdot 1 \\
2 \cdot 1\end{array}$ & $\begin{array}{l}2 \cdot 3 \\
2 \cdot 4\end{array}$ \\
\hline $\begin{array}{l}49 \text { Non-miners' wives } \\
\text { Before husbands' retirement } \\
\text { After husbands' retirement }\end{array}$ & $\begin{array}{l}33 \\
32\end{array}$ & 62 & $\begin{array}{l}131 \\
193\end{array}$ & $\begin{array}{l}67 \\
65\end{array}$ & $\begin{array}{l}1 \cdot 9 \\
2 \cdot 2\end{array}$ & $\begin{array}{l}2.1 \\
2.7\end{array}$ \\
\hline
\end{tabular}




\section{Discussion}

The number of surgery consultations sought by the 79 miners fell from 836 in the year before retirement to 206 in the year following retirement. It is unlikely that these men were healthier at the age of 65 years than they were at the age of 64 years. Consequently it appears likely that much of the surgery workload among these miners in the year before retirement arose out of a need to justify unfitness for work through the agency of a doctor. To a lesser extent this also appears to be true of the non-miners.

Why should there be such a need to justify unfitness for work among miners? For the most part the answer lies in the nature of the work which is often physically demanding and unpleasant. Frequently the work appears dangerous and on occasion the danger is real. It is not surprising, therefore, that these men should be unable to work with an illness or injury or other disability which would not incapacitate them in other occupations. In particular, it is not surprising that the older miner approaching retirement should be most affected. Nevertheless it would be of value to investigate this problem of certification of unfitness for work further, and to go into the question of the home visiting workload at this time of life. Further studies are now in progress on these aspects.

\section{SUMmary}

Seventy-nine miners had over four times as many surgery consultations in the year before their retirement at 65 years than in the year following; the proportion consulting, the number of episodes per person, and the number of consultations per episode were all greater. Fifty-five non-miners had 1.7 times as many consultations in the pre-retirement as in the post-retirement year; the same proportion consulted, but they had more episodes and consultations per episode.

No differences of any significance were seen in the pattern of consultation by wives, either before or after their husbands' retirement, or between miners' and non-miners' wives.

The most likely reason for the consultation pattern among miners seems to be their need for medical certificates to justify unfitness for work.

We are indebted to Dr. R. M. L. Anderson, Dr. J. S. Pollock, Dr. J. G. Rider, Dr. R. B. Charnock, and Dr. J. L. Hall of the Stainforth and Dunscroft Practice, and to Dr. A. H. Smith of Stainforth, for access to records. We are also indebted to Professor J. Knowelden, Dr. M. T. Lunn, and Dr. S. M. Johnston for help and advice, and to Miss J. Pickering, Miss M. Beddard, and Mrs. M. McAfee for secretarial help.

\section{REFERENCES}

LEES, D. S., and COOPER, M. H. (1963). The work of the general practitioner. J. Coll. gen. Practit., 6, 408.

Registrar General (1957). Decennial Supplement, England and Wales, 1951. Occupational Mortality, Part II, Vol. 2: Tables.

Research Committee of the Council of the College of General Practitioners (1962). Studies on Medical and Population Subjects No. 14. Morbidity Statistics from General Practice, Vol. III. (Disease in General Practice). General Register Office.

Rider, J. G., Waters, W. H. R., Charnock, R. B., and LUNN, J. E. (1969). A study of workload in a mining area practice. J. roy. Coll. gen. Practit., 17, 361. 